\title{
Articles
}

大学入試英語問題語彙の難易度と有用性の時代的 変化

\section{A Chronological Study of the Level of Difficulty and the Usability of the English Vocabulary Used in University Entrance Examinations}

\author{
長谷川修治（はせがわ しゅうじ） \\ 千葉県立茂原高等学校 \\ 中條清美（ちゅうじょう きよみ） \\ 日本大学 \\ 西垣知佳子（にしがき ちかこ） \\ 千葉大学
}

Entrance exams at the university level in Japan contain a particular type of English vocabulary known as "juken-eigo," which is specifically employed in entrance examinations and has - in some cases_no other practical application. It has been noted that such juken-eigo vocabulary is comprised of high-level words that are not even included in junior and senior high school (JSH) English textbooks. This study undertakes (a) to scrutinize the language used in the Examination of the National Center for University Entrance (Center exams) and the entrance exams administered by the individual universities (University exams) and (b) to discover how the language compares with the vocabulary to which students are introduced in JSH textbooks. Because Japan's Ministry of Education, Science, and Culture revises its Course of Study Guidelines approximately every ten years,

JALT Journal, Vol. 28, No. 2, November, 2006 
exams from 1988, 1998, and 2004 were chosen to be used as samples for the study. The authors reviewed three Center exams and 48 university exams that had been administered during those years and they made quantitative/ qualitative observations about the juken-eigo vocabulary.

To complete the study, the changes in the characteristics of juken-eigo vocabulary were observed, by year, from the following five aspects: (a) the total number of words (types and tokens) used in Center and in university examinations, respectively; (b) the coverage of JSH English textbook vocabulary for individual Center and University exams; (c) the vocabulary level of Center and university exams with respect to the level presented in JSH English texts, then compared to the high-frequency words of the British National Corpus (BNC); (d) the number of outstanding juken-eigo words in the University examinations, as identified from available usage statistics and compared with the high-frequency words of the $\mathrm{BNC}$; and (e) the scope of the vocabulary used in the University exams compared with the coverage of the related JSH textbooks, with regard to seven practical applications in spoken English and in written English, respectively.

The study reveals that students are expected to be familiar with more words every year and that there are a higher percentage of juken-eigo words appearing in the individual University exams than in the Center exams. This study data shows that the juken-eigo vocabulary used in University exams is, in fact, above the level taught in JSH English textbooks, while the vocabulary used in the Center exams is very nearly appropriate for students who have just graduated from a senior high school in Japan. The authors discuss the implications of those findings and of the data collected when the vocabulary in respective entrance exams was compared with the high-frequency words of the BNC.

Although there is some controversy over the esoteric nature of some of the words used in the vocabulary of university exams, it is important to note that, as time passes, the words deemed to be a part of the juken-eigo vocabulary are more in line with current events and practical spoken applications than are the words presented in the standard JSH textbook vocabulary. The fact is that if the public's increasing demand for practical communicative English language ability is taken into account, a student's modest vocabulary can be supplemented with much of the juken-eigo vocabulary such as that used in the university exams. During the study, it was noted that the level of usability exhibited in the "exam vocabulary" has increased, slightly-in both spoken and written English. It is the authors' contention, however, that students can be better prepared for the entrance examinations if the level of vocabulary used in the university exams was brought more into line with what students actually study when they are in school. This study provides valuable information and basic data, which can provide a solid foundation for the important discussion about what an entrance examination should be.

日本の大学入試英語問題の英語は「受験英語」と呼ばれ、大学に入るための特殊な英語であ ると一般には考えられる。またその語彙の難易度は、文部（科学）省の学習指導要領に基づ く中高英語教科書語彙のそれを超えて、難しすぎるのではないかと言われる。そこで本研究 
は、大学入試英語問題全体に使用される英語語彙の難易度と有用性を、1980年代以降を 3 年 代に分けて定量的・定質的に調査し検証することを目的とした。調査分析は、（1）異語数 と延べ語数、（2）中高英語教科書語彙によるカバー率、（3）British National Corpusを基準尺 度にした語彙レベル、（4）特徵語の抽出、（5）音声英語と文字英語の各 7 分野に対する力 バー率の測定、という5 項目で実施した。結果からは、共通一次・センター試験問題語彙の 難易度はほぼ啇切であるのに対し、個別大学入試英語問題語彙のそれは高すぎることが確認 された。一方、個別大学入試英語問題語彙の有用性は高いことが判明した。

\section{1.はじめに}

日本の大学入試英語問題で扱われる英語は、入学試験のための特殊な英語 とされ、いわゆる「受験英語」と称される。「受験英語」の起源は、明治36年（ 1903）に出版された南日恒太郎著『難問分類英文詳解』にあるとされるが（川 澄, 1978; 若林, 1988）、以来100年以上たった現在、「さすがに珍問、奇問は少 なくなったものの、中学から高校へどんな勉強をしてきた受験生なのかという 認識が欠如している問題を平気で出す大学も目につく」(田崎, 2000：19) という 指摘がある。関連して、Watkins他（1997）は、受験英語についての特質と出題 に関わる諸問題を具体的に分類し、「現在のような難解な、高校教育を全く無視 したような入試問題がある限り受験生の負担は増えるだけである」（p. 50）と述 べている。同様の意見は、新里（1990）、酒井（1996）、小林（2000）などに も見られる。

一方、別府（2003）によれば、昨今の大学入試の英語問題は「英文和訳問題 や細かい文法問題が中心」という「イメージ」から脱却し、「長文問題や会話問 題の増加」、「細かい知識を問う問題の減少」、「私立大学入試問題における英 文和訳問題の比重の小ささ」が「現実」であるという1。さらに深沢（1999）は、 1989～1998年の10年間の国立大学約60の入試英語のライティング問題の推移を 問題形式別に調査した結果、和文英訳の減少と自由英作文の増加を認め、ライ ティングにおいても入試問題は変化していることを報告している。

このような英文読解やライティングにおける問題形式の変化、特殊な構文 ・文法および頊末な知識を問う問題の減少を歓迎する声に対し、大学入試の英 語問題に使用される「語彙」の難易度が依然として高すぎるのではないかという 指摘がある。たとえば、小林（2003）は1982年度と2002年度の入試問題を各 1000 題無作為に選び比較したところ、長文で使用される頻出単語に有意な差は 無かったという。したがって、学習指導要領が改訂され、「中高で学習する単語 数が少なければ少ないほど、入試の語彙レベルとの差が大きくなり、それだけ 受験対策のための負担が大きくなる」（p. 8）と述べている。

関連調査として、長文読解問題に使用される語彙の難易度について、中條・ 長谷川（2004）は、中高英語教科書語彙のカバー率 ${ }^{2}$ はリーダビリティ ${ }^{3}$ 観点 から、過去10年分（1993～2002）のセンター試験と2002年実施の国公立・私立 合計 26 大学 40 学部の入試問題を分析した。その結果、センター試験では年度に よる差は多少あるものの、語彙のカバー率とリーダビリティからはほぼ適正な レベルと判定された。一方、個別の大学入試問題では、中高英語教科書語彙で 対応できる問題は 4 学部 $(10 \%)$ 、高校卒業レベルとして適切なリーダビリテ イのものは12学部（30\%）にとどまっだ。また、Matsuo（2000)は1991年から 1997年までのセンター試験 7 年分、および国公立・私立各 60 大学の入試英語読 
解問題と高校教科書7種類を比較し、その語彙の重なり量から高校教科書だけで は大学入試に対応できないという深刻な状況を報告している。

さらに、長文読解問題だけでなく、文法や語彙に関するテスト項目なども 含めた試験問題全体で使用される語彙を対象にした調査に長谷川（2003）があ る。長谷川はセンター試験を対象に、中高英語教科書語彙のカバー率を1993〜 2002年の10年間にわたって通時的調査をした。その結果から、センター試験に おいては、高校で難易度上級の教科書を使用した場合でも、カバー率がテキス 卜理解の閾值 ${ }^{5}$ される $95 \%$ に達しない年度が多いことを報告している。しかし ながら、個別の大学入試問題については、問題全体で使用される語彙の難易度 を調査した報告はこれまでに無い。

近年、大学生の学力低下が問題となっているが、大学生の学力低下が指摘さ れ始めたのは1990年代であると言われる（佐藤, 2001; 苅谷, 2003）。また、大学 生の学力は小学校から高等学校までの学習の積み重ねであるとすれば、英語は 中・高の学習の積み重ねである。伊村（2003：117）によれば、中・高で学習さ れる英語の新語数の合計は、昭和 26 年 (1951) 以来、学習指導要領が約10年ご とに改訂されるたびに減少している。大学生の学力低下との関連で、1990年代 とその前後を見れば、1980年代、1990年代、2000年代の順で、2,300〜2,950語 $\rightarrow$ 2,900 語 $\rightarrow 2,700$ 語となっている。したがって、実際に大学入試に出題される英語 問題語彙の難易度を判定するためには、中高英語教科書語彙との関係で、この ような時代的な変化を考慮にいれた調査が必要であると考えられる。

そこで、様々な議論がある日本の大学入試英語問題の現状に鑑み、センタ 一試験および個別の大学入学試験の英語問題全体について、中高英語教科書語 彙から見た語彙の難易度を、時代の推移にしたがって調査することにした。調 査年代は、大学生の学力低下が指摘されだした1990年代を中心に、1980年代、 1990年代、2000年代という時代区分で行った。また同時に、昨今、急速に高ま りつつある実践的コミュニケーション能力育成のための英語教育において、「大 学入試英語問題語彙」がどの程度寄与できるかを、有用性 ${ }^{6}$ 面から定量的・定 質的に調査することにした。そして、大学での英語教育を効果的に行う上で、

「中高英語教科書語彙」に「大学入試英語問題語彙」を加えた、大学入学時の英語 学習者の語彙力の上限7を時代の推移とともに実際の使用場面を想定して推定し ようと試みた。

\section{2. 研究の目的}

大学入試英語問題（共通一次・センター試験問題 ${ }^{8}$ 、および国公立 ${ }^{9}$ ・私立大 学の個別試験問題）に使用される語彙の難易度が、中高英語教科書語彙から見 て適切であるかを、1980年代、1990年代、2000年代の時代区分により定点観察 をする。また同時に、大学入試問題の語彙が時代の推移とともにどのような量 的・質的変化を遂げているかを、実際の使用場面を想定した有用性に対し、大 学入学時の学生の語彙レベルの上限という視点から調査する。なお、本稿にお ける「有用性」とは、「日本人英語学習者に必要とされ、実際に役立つこと」と定 義する。

上記の研究目的を遂行するため、具体的な調査項目は下記の 5 点とする。大 学入試問題語彙の「難易度」に関する調査が（1）〜（4）、「有用性」に関する調 査が（5）である。 
（1）各入試問題の延べ語数と異語数

（2）各入試問題に出現した語彙に対する中高英語教科書語彙の割合(カバー率)

（3）各入試問題および中高英語教科書語彙の語彙レベル

（4）年代別16大学合計入試問題語彙10に顕著に出現した語（特徵語）

（5）年代別「中高英語教科書 +16 大学合計入試問題」語彙の有用性の計測

\section{3. 研究の方法}

\section{1 調查対象とする言語材料}

1980年以降の高等学校学習指導要領の改訂施行年度は、1982年、1994年、 2003年であり、各々 3 年後が当該学習指導要領で学習した生徒の最初の大学 入学試験となる。したがって、2003年施行の学習指導要領による大学入試は 2006年の開始である。さらに、中・高学習指導要領の接続年度がずれている年 がある11ことを考慮に入れて、1988年、1998年、2004年の大学入試を調査対象と した。大学入試問題は、共通一次・センター試験問題と、一般に難関校と言わ れ学習者が目標とすると考えられる国公立・私立の16大学（国公立 8 大学、私 立 8 大学) ${ }^{12}$ の個別試験問題を選定した。比較対象とする中・高英語教科書は、 各入試年度に対応した高校英語教科書を基準とした。13詳細は下記のとおりであ る。

\section{（1）共通一次・センター試験英語問題}

1988年実施共通一次試験（本試験）、および1998年と2004年実施のセンター 試験（本試験）とし、次のデータベースから必要部分を使用した。

『センターTen 英語』（ジェイシー教育研究所, 2003)

『センターTen Plus 英語』（ジェイシー教育研究所, 2004）

\section{（2）大学個別入学試験英語問題}

将来英語を使用する機会が比較的多いと考えられる学部・学科で、3 年代を 通じて同一大学での比較が可能となるように、1988年、1998年、2004年実施の 国公立 8 大学、私立 8 大学、合計 16 大学の文学部（英文科）もしくは経済学部 の問題とした。14国公立 8 大学の内訳は、旧帝国大学 4 校（東京大学、東北大 学、京都大学、九州大学）、首都圈新制大学 4 校（筑波大学、千葉大学、横浜 国立大学、東京都立大学 15 ) 、私立 8 大学の内訳は、東京都内 4 大学（早稲田、 慶應義塾、上智、青山学院）、関西圏 4 大学（関西学院、関西、同志社、立命 館）である。使用した資料とデータベースは、次のとおりである。

『昭和63年 全国大学入試問題正解 英語 国公立大編』（旺文社, 1988）

『昭和63年 全国大学入試問題正解 英語 私立大編』（旺文社, 1988）

『Xam’98 全国大学入試問題データベース 英語』（ジェイシー教育研究所, 1998)

『Xam 2004 全国大学入試問題データベース 英語』（ジェイシー教育研究所, 2004) 


\section{（3）中学・高等学校英語教科書}

中学校から高等学校までひとりの生徒が英語学習のために使用する教科 書は、中・高で各 1 シリーズの教科書であることが多いので、中・高ともに 1980年代から2000年代まで採択数上位にあった教科書シリーズより選定した（ cf.『内外教育』，『教科書レポート』）。高等学校用は、大学進学者の多い 普通高校で一般に使用されると考えられる「英語 I」「英語 II」「リーディング（ 1980年代は英語 II B）」とした。本調査で使用した教科書は以下のものであり、 各教科書の「各課の本文」と「Supplementary Reading」を調査対象とした。

中学校 : New Horizon 1, 2, 3 (東京書籍, 1988, 2000)

高等学校 : Unicorn I (文英堂, 1987, 1997), II (ibid., 1988， 1998)，

Reading (ibid., 1999), II B (ibid., 1988)

\section{2 調查項目の分析方法}

本調査で使用した言語材料は、電子化されているものはデジタルデータを利 用し、電子化されていないものはスキャナを使用して入力後、校正し、単語の 変化形を基本形に集約した語彙リストを作成した。特定のテキストに多く出現 して計測結果に影響を与えやすい固有名詞・数詞・略語・間投詞・記号は削除 した。加えて、大学入試英語問題から注釈の付いている語を全て削除した。

言語材料のうち、1980年代から2000年代までの大学入試英語問題語彙の時 代的変化を多角的に探るため、1988年、1998年、2004年の各々共通一次・セン 夕一試験問題語彙と個別大学試験問題語彙に対する比較調査 5 項目の分析方法 は、下記（1）〜（5）のとおりである。

\section{(1) 各入試問題の延べ語数と異語数}

本研究では、読解問題のみならず文法や語彙に関する問題等も含めた各入試 問題全体で使用される語彙の量的変化を探るため、各問題で使用される英単語 の延べ語数と異語数を求めて、年代順に比較した。

\section{（2）各入試問題に出現した語彙に対する中高英語教科書語彙の割合(カバー率)}

各入試英語問題の延べ語数に対し、その何％を中高英語教科書語彙でカバー できるかを、年度ごとに求めて比較した。現在、語彙研究の分野では英文の内 容を理解するためには、当該英文の $95 \%$ 以上にあたる語彙数が最低限必要であ ろうというとらえ方をする研究者が多いようである（Laufer，1997；投野，1997; Read, 2000; Nation, 2001; 林, 2002）。そこで、本研究でも難易度の判定にあたつ ては、「95\%カバー率」をひとつの目安とした。

\section{（3）各入試問題および中高英語教科書語彙の語彙レベル}

本研究ではBritish National Corpus (BNC)を基準尺度とし、その頻度上位何語で 各入試問題および教科書の語彙を $95 \%$ 以上カバーできるかを算定する手法で、 入試問題と中高英語教科書の語彙レベルを推定した。「95\%」という基準は、上 記Laufer（1997）等による。基準尺度に用いたリストは、Chujo （2004）で作成し たBNC頻度上位13,994語である。 


\section{（4）年代別16大学合計入試問題語菓に顕著に出現した語（特徽語）}

「受験英語」という特定分野の英文の特徵を強く反映する語を抽出するに は、対数尤度比という統計指標を利用することができる（Scott， 1999; 中條他， 2005）。本研究では各年代別に16大学の入試問題を集めた入試語彙の総リス トと、上述のBNC頻度上位13,994語を対数尤度比を用いて統計的に比較し、 BNCのような汎用の英文資料の語彙出現状況に比べ、入試問題に顕著な出現状 況を示す語を抽出した。

\section{（5）年代別「中高英語教科書 +16 大学合計入試問題」語彙の有用性の計測}

日本人英語学習者が高校卒業後に大学生となり、グローバル化社会の中で生 きるために必要とされる英語という観点から、音声英語と文字英語、各 5 領域 7 分野の英文に対する「中高英語教科書語彙と 16 大学入試問題語彙の総和」によ るカバー率を計測し、年代別に比較した。その結果は、長谷川・中條（2004） で調査した英語教科書語彙の有用性の計測結果とも比較できるように、表1に示 した英文資料16を用いて有用性の指標とした。

特に、「英語コミュニケーション能力試験」については、文部科学省（2003） の「『英語が使える日本人』の育成のための行動計画」に示された英語の到達目 標として使用される指標の中から、TOEIC とTOEFLという 2 分野の言語材料 を用意した。同様に「情報収集」についても、中條・長谷川（2003）を参考にし て、日本人英語学習者が到達目標にすると考えられるもの（PBS， TIME）と、 初心者向けの教育的配慮のあるもの（VOA, News for You）という観点から 2 分 野ずつとした。

表1大学入試問題の有用性の計測に用いた英文資料

\begin{tabular}{|l|l|l|}
\hline & \multicolumn{1}{|c|}{ 音声英語 } & \multicolumn{1}{c|}{ 文字英語 } \\
\hline 英語コシュニケ-ショ能力試験 & $\begin{array}{l}\text { TOEIC } \\
\text { (リスニング・セクション) }\end{array}$ & $\begin{array}{l}\text { TOEIC } \\
\text { (リーディング・セクション) }\end{array}$ \\
\hline & $\begin{array}{l}\text { TOEFL } \\
\text { (リスニング・セクション) }\end{array}$ & $\begin{array}{l}\text { TOEFL } \\
\text { (リーディング・セクション) }\end{array}$ \\
\hline 大学留学 & チュートリアル & 大学入学案内 \\
\hline 情報収集 & PBS (TVニュース) & TIME (英文雑誌) \\
\hline & VOA (ラジオ・レポート) & News for You (ESL英字新聞) \\
\hline 日常生活 & サバイバル英語 (生活英語) & 生活案内 \\
\hline 趣味・教養 & 映画 (Titanic) & 小説 (Harry Potter) \\
\hline
\end{tabular}

カバー率の計測は、信頼性の高い計測結果を得るため、Chujo＆ Utiyama （2005a，2005b）を参考にして、分野ごとに1,500語のサンプルを 5 個無作為に 抽出し、その各々に対するカバー率を求め、その平均值を使用した。なお、 
TOEIC とTOEFLは試験問題という性格上、問題全体を対象とし、リスニング・ セクションとリーディング・セクションについてそれぞれ 2 回分の試験問題の カバー率を計測し、その平均值を使用した。TOEICとTOEFLは、それぞれリス ニング・セクションとリーディング・セクションの延ベ語数が各々 3,000 語以上 あることから、サンプル 2 個の平均でも安定した結果を得られると判断した（ Chujo \& Utiyama, 2005a; 2005b)。

\section{4. 結果と考察}

\section{1 延べ語数と異語数}

共通一次・センター試験、個別大学入試の各英語問題に使用された英語の語 彙について、1988年、1998年、2004年でそれぞれ延べ語数と異語数を計測した 結果を表 2 に示した。個別大学は国公立と私立に分類し、そのカテゴリーの中 で2004年の異語数が降順になるようにした。最下段に示した平均值は、国公立 ・私立を合わせたものである。

表2 大学入試問題に用いられた語彙数の変化（単位 : 語)

\begin{tabular}{|c|c|c|c|c|c|c|}
\hline & \multicolumn{2}{|c|}{ 1988年 } & \multicolumn{2}{|c|}{ 1998年 } & \multicolumn{2}{|c|}{ 2004年 } \\
\hline & 異語数 & 延べ語数 & 異語数 & 延べ語数 & 異語数 & 延べ語数 \\
\hline 共通一次・センター試験 & 635 & 2541 & 657 & 3005 & 639 & 2943 \\
\hline \multicolumn{7}{|l|}{ 国公立大学 } \\
\hline 東京 & 584 & 1872 & 465 & 1795 & 682 & 2403 \\
\hline 筑波 & 335 & 846 & 493 & 1370 & 597 & 1748 \\
\hline 九州 & 475 & 1452 & 470 & 1411 & 556 & 1391 \\
\hline 東北 & 512 & 1593 & 662 & 2126 & 482 & 1721 \\
\hline 東京都立 & 344 & 869 & 405 & 1073 & 451 & 1380 \\
\hline 横浜国立 & 522 & 1671 & 552 & 1553 & 432 & 1480 \\
\hline 千葉 & 437 & 1682 & 666 & 1996 & 420 & 1199 \\
\hline 京都 & 224 & 646 & 309 & 745 & 359 & 892 \\
\hline \multicolumn{7}{|l|}{ 私立大学 } \\
\hline 立命館 & 438 & 1603 & 781 & 3486 & 923 & 4241 \\
\hline 上智 & 584 & 1998 & 650 & 2487 & 838 & 3207 \\
\hline 関西 & 500 & 1493 & 620 & 2049 & 685 & 2691 \\
\hline 同志社 & 457 & 1435 & 672 & 2535 & 650 & 2640 \\
\hline 早稲田 & 470 & 1156 & 761 & 2553 & 623 & 2021 \\
\hline 関西学院 & 596 & 2043 & 570 & 1815 & 595 & 2005 \\
\hline 青山学院 & 399 & 1427 & 446 & 1429 & 419 & 1307 \\
\hline 慶應義塾 & 426 & 1400 & 354 & 790 & 397 & 1085 \\
\hline 国公立私立大学平均 & 456 & 1449 & 555 & 1826 & 569 & 1963 \\
\hline
\end{tabular}

表 2 から、共通一次・センター試験では、延べ語数が年代別に、2541語 $\rightarrow$ 3005語 $\rightarrow 2943$ 語となっており、80年代と比較して90年代と2000年代が相対的に 多い。異語数では、635語 $\rightarrow 657$ 語 $\rightarrow 639$ 語と、ほぼ延べ語数の多寡に比例してい 
る。

個別大学入試問題の延べ語数と異語数を年代別に平均値で比較すると、延べ 語数は、1449語 $\rightarrow 1826$ 語 $\rightarrow 1963$ 語となっており、試験で使用される英語の分量 が年代ごとに増加している。また、異語数は、456語 $\rightarrow 555$ 語 $\rightarrow 569$ 語と、使用さ れる語の種類も増加している。したがって、近年の入試英語の特徴のひとつで ある「読解問題の長文化」（安竹内, 1997）が、試験問題全体の語彙数の増加に反 映しているのではないかと考えられる。

\section{2 入試問題語彙に対する中高英語教科書語彙の割合 (カバー率)}

中高英語教科書の語彙で個々の入試問題の延べ語数の何％の語が既習とな るかというカバー率を計測した結果を、年代別に表 3 に示した。国公立・私立 ごとに2004年のカバー率で降順に示してあり、最下段の平均值は国公立・私立 を合わせたものである。なお、中高英語教科書の異語数は、80年代 : 2779 語、 90年代と2000年代：3098語であった。

表3 入試問題における中高英語教科書語彙のカバー率（単位：\%）

\begin{tabular}{|c|c|c|c|c|}
\hline & & 1988年 & 1998年 & 2004 年 \\
\hline 共通一 & 次・センター試験 & 94.8 & 96.4 & 96.4 \\
\hline \multicolumn{5}{|c|}{ 国公立大学 } \\
\hline & 東京 & 92.9 & 95.8 & 93.9 \\
\hline & 東京都立 & 88.5 & 90.5 & 92.9 \\
\hline & 横浜国立 & 87.7 & 85.6 & 92.6 \\
\hline & 千葉 & 93.5 & 88.7 & 92.2 \\
\hline & 東北 & 89.6 & 91.4 & 91.9 \\
\hline & 京都 & 87.0 & 88.6 & 91.0 \\
\hline & 筑波 & 92.7 & 87.1 & 89.6 \\
\hline & 九州 & 90.7 & 89.9 & 85.4 \\
\hline \multicolumn{5}{|c|}{ 私立大学 } \\
\hline & 関西 & 88.3 & 89.8 & 93.1 \\
\hline & 関西学院 & 88.4 & 90.7 & 91.6 \\
\hline & 早稲田 & 88.1 & 88.9 & 90.1 \\
\hline & 上智 & 89.5 & 93.4 & 89.7 \\
\hline & 同志社 & 87.7 & 88.8 & 89.7 \\
\hline & 慶應義塾 & 89.8 & 84.7 & 86.6 \\
\hline & 立命館 & 93.0 & 92.3 & 86.3 \\
\hline & 青山学院 & 89.6 & 87.9 & 83.5 \\
\hline 国公立 & 私立大学平均 & 89.8 & 89.6 & 90.0 \\
\hline
\end{tabular}


表 3 において、共通一次・センタ一試験に対する中高教科書語彙のカバー率 は、年代順に $94.8 \% \rightarrow 96.4 \% \rightarrow 96.4 \%$ \% たがって、共通一次・センター試験で使用された語彙の選定は、概ね適切であ つたと考えられる。また、90年代と2000年代のカバー率が、80年代に比較して 上昇しているということは、近年、センター試験が易しくなつたのではないか と言われる（cf. 片山他, 1997; 谷口, 1997; 武田, 2004）一因を裹付けるものと考 えられる。

個別大学入試問題に対する中高英語教科書語彙のカバー率を年代ごとに平均 で比較すると、89.8\% $\rightarrow 89.6 \% \rightarrow 90.0 \%$ とな、約 $90 \%$ でほんど変化が無い。 ただし、カバー率が $90 \%$ 以上の大学数は、80年代と90年代がそれぞれ 5 校、6 校であるのに対し、2000年代は 9 校に増加している。したがって、近年、出題 者側にも、大学入試問題語彙に対する配慮が現れ始めているのではないかとも 考えられる。中でも興味深いのは、受験生にとっては最難関の東京大学が、 国公立・私立両大学の中で、80年代 $92.9 \% （ 3$ 位）、90年代 $95.8 \%$ （1位）、 2000年代93.9\%（1 位）、と一貫して90\%を超え上位にあることである。

\section{$4.3 \mathrm{BNC}$ 基準尺度とした入試問題の語彙レベル}

各入試問題の語彙レベルは、対応する中高英語教科書語彙と比較すると相対 的にどのような位置付けになるのかを、BNC頻度上位語の語数で表して比較し た結果を図1に示した。図の数字は各試験・教科書語彙を $95 \%$ カバーするのに必 要なBNC頻度上位語の語数である。図には年代ごとに各試験における語彙レべ ルの平均值と、学習者の語彙レベルを表すと考えられる中高英語教科書の語彙 レベルを示した。大学受験者は中学と高校の教科書を使用して英語の基本的部 分を学習してきているため、中高英語教科書語彙が彼らの語彙レベルの目安と 考えられる。

図 1 から、共通一次・センター試験は年代順に、2185語レベル $\rightarrow 2534$ 語レ ベル $\rightarrow 1903$ 語レベルであり、いずれも対応する中高教科書の語彙レベル（80年 代：3295語レベル、90年代と2000年代：3299語レベル）より低いので、高校修 了時の英語の学力をみる試験として適切なレベルであると考えられる。

一方、個別大学入試問題の語彙レベルは年代別平均で、4125語レベル $\rightarrow$ 4435語レベル $\rightarrow 4224$ 語レベルであり、対応する中高教科書の語彙レベルと比較 して、明らかに難易度が高いと考えられる。図 1 には平均值のみを示したが、 個々に観察した大学入試問題の語彙レベルからも、国公立・私立に関わりな く、各年代を通じて全ての大学入試問題が中高教科書の語彙レベルを超えてい たことも確認されたことを付記する。

\section{4 大学入試英語問題の特徽語}

大学入試問題を特徽付ける語を、対数尤度比を用いて、一般的な英語使用を 代表すると考えられるBNCと比較することによって抽出し、その特徵度の強い 順に上位 20 語を表4に示した。なお、調査対象となった 16 大学入試英語問題の総 和から求めた異語数は、1988年：2934語、1998年：3407語、2004年：3432語で あった。 


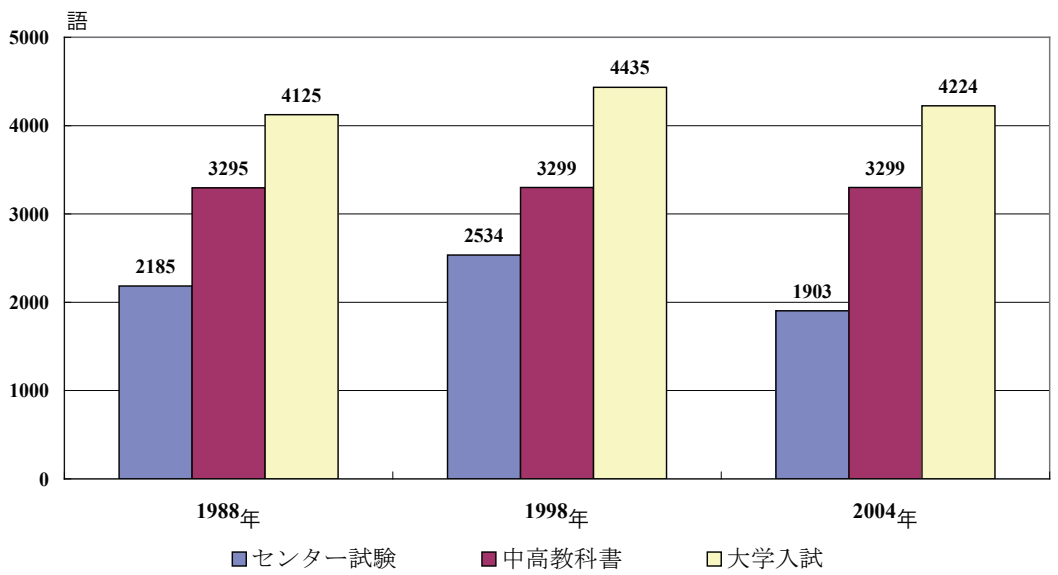

図1 入試問題と中高教科書の語彙レベルの年代別比較

表 4 から、各年代における各入試問題の特徴語第 1 位にランクされた語は、 1988年 : fast-food、1998年 : language、2004年 : fishである。これらの語と上位 20位以内に入った他の語を合わせて考えると、88年はrestaurant, fry, food, corn など「食文化」について、98年は listen, information, learn, communication など「言 語」について、04年は overfish, shrimp, aquaculture, fisher, preservation, mangrove な ぞ「自然保護」についてのトピックが、大学入試問題の、特に長文読解問題の特 徵をなしていたのではないかと推察される。17さらに、98年はtsunami, deep-sea, dolphin, oceanなど「海洋」について、child, family, parent, human など「家族関係」 についてのトピックも考えられる。

2004年度入試に出題された長文問題のトピックを分析した旺文社（2004a, 2004b）によれば、国公立・私立いずれも上位 3 位までは、「文化」「日常生 活」「自然」の順で合計70\%以上を占めている。表 4 からは、このようなトピック が1980年代より続いているのではないかということが推測できる。

大学入試問題に出題されるトピックは、その時代に関心を集めた事柄が取り 上げられる可能性が高いのは、受験関係者には周知の事実である。時の話題に 関するキーワードをその都度学習しておくことは、実践的コミュニケーション 能力を高める上でも重要なことと考えられる。受験生にとっては、特定のトピ ツクと関連語彙の知識が合否に影響を与えることも示唆されている（Brown＆ Yamashita, 1995a: 27）。また、大学入試の望ましくない波及効果が強調される なかで、本来あるべき望ましい波及効果として、Mulvey（1999: 132)は、読解ス キルの習得等のほかに語彙の補強を挙げている。このことから、視点を変えた 入試問題の利用もありえるのではないかと考えられる。ただし、あくまでも受 験生の学習負担が過剰にならないような配慮をすべきことは言うまでもない。 
表4 大学入試問題の特徵語

\begin{tabular}{|r|l|l|l|}
\hline 順位 & \multicolumn{1}{|c|}{1988 年入試 } & \multicolumn{1}{|c|}{1998 年入試 } & 2004年入試 \\
\hline 1 & fast-food & language & fish \\
\hline 2 & snake & child & tooth \\
\hline 3 & blacksnake & deep-sea & print \\
\hline 4 & restaurant & patina & overfish \\
\hline 5 & fry & family & shrimp \\
\hline 6 & weighing-machine & dolphin & dentist \\
\hline 7 & food & alcohol & tear \\
\hline 8 & frontier & ocean & baby \\
\hline 9 & mother & listen & advertiser \\
\hline 10 & we & dream & aquaculture \\
\hline 11 & dead & information & fisher \\
\hline 12 & resurrection & facial & culture \\
\hline 13 & lecture & parent & mathematics \\
\hline 14 & author & we & preservation \\
\hline 15 & gentility & oxidize & recreational \\
\hline 16 & philosophize & preiudge & gender \\
\hline 17 & doublet-and-hose & learn & people \\
\hline 18 & corn & communication & difference \\
\hline 19 & I & human & mangrove \\
\hline 20 & civilization & & \\
\hline & & & \\
\hline
\end{tabular}

\section{5 入試英語語彙の有用性}

受験生は受験準備として過去に出題された入試問題を学校の内外で使用す るため、本研究では、大学入学時の学生の語彙力の上限を、中高教科書語彙に 加えて、今回調査に使用した16大学の入試問題語彙を全て習得した場合と仮定 した。その際、どの程度の有用性が期待できるかを、音声英語と文字英語につ いて各 5 領域 7 分野で計測した。結果はそれぞれ表5 と表6に示した。表中の各 年代において、左列がその年代に使用された中高英語教科書のみによるカバー 率、右列（網掛部分）が「中高英語教科書 +16 大学入試英語問題」によるカバー 率である。最下段には、各々 7 分野の平均カバー率と未知語に遭遇する割合 ${ }^{18}$ 示した。なお、1990年代と2000年代では、受験生の学習した教科書語彙が共に 90年代の学習指導要領に基づいているため、左列の数值が等しくなっている。 調査対象とした「中高英語教科書 +16 大学入試英語問題」の異語数は、1988年： 4170語、1998年 : 4664語、2004年：4662語であった。 
表5＼cjkstart年代別に見た教科書と入試語彙の音声英語の英文資料に対する有用性

\begin{tabular}{|c|c|c|c|c|c|c|c|}
\hline & \multirow{3}{*}{ 音声英語 } & \multicolumn{2}{|c|}{1980 年代 } & \multicolumn{2}{|c|}{1990 年代 } & \multicolumn{2}{|c|}{2000 年代. } \\
\hline & & 80 年代 & +88 年 & 90 年代 & +98 年 & 90 年代 & +04 年 \\
\hline & & 教科書 & 入試 & 教科書 & 入試 & 教科書 & 入試 \\
\hline \multirow[t]{2}{*}{ 英語亲ケーション能力試験 } & TOEIC (リスニンク•セクション) & 90.8 & 93.9 & 91.7 & 94.6 & 91.7 & 95.2 \\
\hline & TOEFL (リスニンク・セクション) & 91.7 & 95.1 & 92.5 & 95.1 & 92.5 & 95.9 \\
\hline 大学留学 & チュートリアル & 91.3 & 94.6 & 92.9 & 96.2 & 92.9 & 96.1 \\
\hline \multirow[t]{2}{*}{ 情報収集 } & PBS (TVニュース) & 87.2 & 90.9 & 89.1 & 92.8 & 89.1 & 93.6 \\
\hline & VOA (ラジオ・レポート) & 88.6 & 92.2 & 90.4 & 94.2 & 90.4 & 95.3 \\
\hline 日常生活 & サバイバル英語 (生活英語) & 97.1 & 98.1 & 96.8 & 97.3 & 96.8 & 97.7 \\
\hline \multirow[t]{3}{*}{ 趣味・教盖 } & 映画 (Titanic) & 92.8 & 94.3 & 93.2 & 94.8 & 93.2 & 94.5 \\
\hline & 平均カバー率（\%） & 91.4 & 94.1 & 92.4 & 95.0 & 92.4 & 95.5 \\
\hline & 未知語に遭遇する割合（語） & 11.6 & 17.1 & 13.1 & 20.0 & 13.1 & 22.1 \\
\hline
\end{tabular}

\subsection{1 音声英語について}

表 5 から、中高英語教科書のみのカバー率で、80年代教科書と2005年 3 月ま で使用されていた 90 年代教科書を比較すると、90年代教科書の方が調査した 7 分野のほぼ全てにおいてカバー率が上昇し、平均值で見ても、91.4\%から92.4\% に上昇している。

次に、教科書語彙に入試語彙を加えた（網掛部分）、(1)「80年代教科書 + 88 年入試」、(2)「90年代教科書 +98 年入試」(3)「90年代教科書 +04 年入試」を比較 すると、指標とした 7 分野に対するカバー率の平均は、(1)から(3)へ向かって、 $94.1 \% \rightarrow 95.0 \% \rightarrow 95.5 \%$ と近年になるにつれて上昇している。結果的に入試問題 語彙を習得すれば、実際の使用場面での有用性の向上が期待できる可能性が見 てとれる。

調査対象とした 7 分野の項目別に見た場合、カバー率が95\%以上になって いるのは、(1)では「TOEFL（リスニング・セクション）」と「サバイバル英語（ 生活英語）」だけであるが、(2)では「チュートリアル」が加わり、(3)ではさらに 「TOEIC（リスニング・セクション）」と「VOA（ラジオ・レポート）」が加わっ て、 7 分野中 5 分野になる。したがって、大学入試問題語彙は、近年では実際 的使用が可能な分野にも広がりを見せていると言える。

近年の時代的変化として見た場合、98年入試と04年入試では、受験生の学 習した教科書語彙が共に90年代の学習指導要領に基づいているため、カバー率 の向上は 98 年と 04 年の入試問題の変化を如実に反映している。したがって、 明らかに 98 年より 04 年の入試問題語彙の方が有用性が高いと考えられる。特 に04年では、TOEICのリスニング・セクションでカバー率が95\%を超えたこと は注目に值する。TOEIC と並んで英語能力判定の資料に利用されることの多い TOEFLにおいては、1980年代ですでに95\%を超えている。一方、TOEICでは 2000年代になってようやく95\%を超えた。昨今、大学英語教育の中でTOEIC対 
策の授業を展開しているところも増えているが、試験問題作成者にもTOEICの 問題が意識されているのではないかと推測できる。

\subsection{2 文字英語について}

表 6 から、まず中高英語教科書のみのカバー率を観察すると、調査した 7 分野に対するカバー率の平均（表中最下段）は、80年代教科書と90年代教科書 とでは83.2\%から85.3\%に上昇している。指標とした 7 分野のそれぞれを見て も、全ての分野でカバー率が上昇している。しかしその90年代教科書でさえ、 95\%カバー率を目安にした場合、音声英語では平均 $2.6 \%(95 \%-92.4 \%)$ 不足 していたのに対し、文字英語では平均 $9.7 \%(95 \%-85.3 \%)$ 不足しており、 英語を聞いて理解する場合にも困難を生じるが、読んで理解する場合には、 それ以上の困難を伴うことが予想される。特に、「生活案内」「TIME（英文雑 誌）」「TOEIC（リーディング・セクション）」の分野におけるカバー率が低い。

\section{表6 年代別に見た教科書と入試語彙の文字英語の英文資料に対する有用性}

\begin{tabular}{|c|c|c|c|c|c|c|c|}
\hline & \multirow{3}{*}{ 文字英語 } & \multicolumn{2}{|c|}{1980 年代 } & \multicolumn{2}{|c|}{1990 年代 } & \multicolumn{2}{|c|}{2000 年代 } \\
\hline & & 80 年代 & +88 年 & 90 年代 & +98 年 & 90 年代 & +04 年 \\
\hline & & 教科書 & 入試 & 教科書 & 入試 & 教科書 & 入試 \\
\hline \multirow[t]{2}{*}{ 英語コミュニケーション能力試験 } & TOEIC (リーディング・セクション) & 80.0 & 87.1 & 81.7 & 88.6 & 81.7 & 89.6 \\
\hline & TOEFL (リーディング・セクション) & 82.9 & 88.9 & 85.2 & 90.8 & 85.2 & 90.7 \\
\hline 大学留学 & 大学入学案内 & 81.9 & 89.6 & 84.0 & 90.5 & 84.0 & 91.1 \\
\hline \multirow[t]{2}{*}{ 情報収集 } & TIME (英文雑誌) & 79.7 & 85.0 & 82.2 & 86.9 & 82.2 & 87.5 \\
\hline & News for You (ESL英字新聞) & 88.5 & 92.3 & 90.2 & 93.4 & 90.2 & 93.9 \\
\hline 日常生活 & 生活案内 & 78.2 & 85.3 & 80.9 & 87.8 & 80.9 & 88.3 \\
\hline \multirow[t]{3}{*}{ 趣味・教養 } & 小説 (Harry Potter) & 91.1 & 93.1 & 92.7 & 93.9 & 92.7 & 94.2 \\
\hline & 平均カバー率 (\%) & 83.2 & 88.8 & 85.3 & 90.3 & 85.3 & 90.8 \\
\hline & 未知語に遭遇する割合（語） & 5.9 & 8.9 & 6.8 & 10.3 & 6.8 & 10.8 \\
\hline
\end{tabular}

一方、教科書語彙に入試語彙を加えた（網掛部分）、(1)「80年代教科書 + 88 年入試」、(2)「90年代教科書 +98 年入試」、(3)「90年代教科書 +04 年入試」を比較 すると、文字英語における実際の使用場面と想定した 7 分野に対するカバー率 の平均は、(1)から(3)向けて、88.8\% $\rightarrow 90.3 \% \rightarrow 90.8 \%$ とわずであるが増加し ている。調査した 7 分野の分野別に見ても、(1) $\rightarrow(2) \rightarrow(3)$ と時代を追うごとに、 ほぼ全ての項目でカバー率が上昇している。とはいえ、どの分野においてもカ バー率が95\%には到達していない。

(3)の「教科書語彙＋04年入試」においてカバー率が相対的に平均（90.8\%）よ り高い分野は、高い順に「小説 (Harry Potter)」（94.2\%）、「News for You（ESL英 字新聞）」(93.9\%)、「大学入学案内」（91.1\%）である。一方において、英語 上級レベルの学生や社会人の目標とする「TIME（英文雑誌）」（87.5\%）や、学 校英語教科書の弱点として指摘されてきた日常生活語彙（中條他, 1993; 長谷川 
• 中條，2004）に該当する「生活案内」（88.3\%）が相対的に低い。大学において は、このような分野の語彙の補強が必要であると言える。とりわけ、中高英語 教科書から大学入試英語問題に至るまで全ての学習段階を通して不足する日常 生活語彙については、その指導に関して特別な配慮が必要であると考える。

近年、英語教育の到達目標值を設定する際にしばしば利用される「TOEIC」と 「TOEFL」において、(3)のリーディング・セクションのカバー率はそれぞれ 89.6\% と90.7\%である。各リスニング・セクションがそれぞれ $95.2 \%$ と $95.9 \%$ で あることを考慮に入れると、大学生のTOEIC、TOEFL両テストの試験対策のひ とつとしては、リーディング・セクション用の語彙を補強する必要があると考 えられる。ただし、中高教科書語彙に大学入試問題語彙を追加することによる カバー率の上昇值を 3 年代で比較すると、90年代教科書語彙に 04 年入試語彙を 追加した場合の「TOEIC」が最大（7.9ポイント： 89.6\%-81.7\%）である。した がって、音声英語と同様に文字英語においても、近年、コミュニケーション能 力試験への関心の高まりが入試問題の作成に影響を与えているのではないかと 推測できる。

\section{5.まとめ}

日本の大学入試英語問題に出題される英語は「受験英語」と呼ばれ、大学に 入るための特殊な英語であって、実際の使用場面ではあまり役立たないのでは ないかと一般に考えられてきた。さらに、その語彙の難易度は、文部（科学） 省の学習指導要領に基づく中高英語教科書語彙のそれを超えて、難しすぎるの ではないかということがしばしば指摘されている。そこで、本研究の目的は、 大学入試英語問題全体に使用される英語語彙の難易度と有用性を、1980年代、 1990年代、2000年代とに分けて実際に調査し検証することであった。

結果から判明したことは、（1）本稿で調査した個別大学入試英語問題語彙 は、異語数と延べ語数が1980年代から2000年代に向けて近年増加しているこ と、（2）中高英語教科書語彙によるカバー率が、共通一次・センター試験問題 語彙では 3 年代を通じてほぼ $95 \%$ 前後であるのに対し、個別大学入試英語問題 語彙は平均 $90 \%$ であること、（3）BNCを基準尺度とした相対的な語彙レベル が、共通一次・センター試験問題語彙では中高英語教科書語彙より低いのに対 し、個別大学入試英語問題語彙では高いこと、 徵語は各時代の話題と関係がありそうなこと、

(4) 個別大学入試英語問題の特 学合計入試英語問題語彙を加えると、カバー率が音声英語では 7 分野中5分野で 95\%以上であるのに対し、文字英語ではどの分野でも $95 \%$ には及ばなかったも のの、音声英語・文字英語共に近年カバー率が上昇しているということであっ た。

ただし、大学入試問題語彙の難易度は、個々の問題の目標や内容等を考慮に 入れた場合、その評価は多少異なる様相を示す可能性もある。また、有用性の 査定では、本研究で調査した 5 領域 7 分野以外にも指標として利用可能なもの もあると考えられる。

このような前提条件に立った上で、本研究の結果から判明したことより、個 別大学の入試英語問題作成にあたっては、使用される語彙が中高英語教科書語 彙の難易度を超えているという、従来からの指摘を充分考慮に入れる必要があ ると考えられる。一方で大学受験生にとつて、受験英語は将来必要となる実際 
の使用場面で役立つ可能性が高いということが確認できたことは、朗報と言え るだろう。また、視点を変えて、大学入試問題を語彙力補強のための牽引車と なる教材として、積極的に利用していこうという方法も考えられる。このよう な現実を踏まえつつ、個別の大学入試英語問題語彙の選定においては、今後、 さらに改善がなされることにより、中・高の教育現場への望ましい波及効果が 高まることを期待したい。

注

1. 別府（2003）がこのように判断するのは、Beppu（2001）、宇都・柳瀬（ 2000）のデータを根拠としている。Beppuは1996〜2000年の 5 年間にわた る国公立 5 大学、私立大学 20 学部、およびセンター試験 5 回分の延べ合計 130 の入試問題を、宇都・柳瀬は1998年の国立40大学・47学部、公立13大学 ・13学部、私立51大学・83学部の全問題から長文問題を対象として調査し た。

2. カバー率（coverage）とは、ある語または語の集合が、テキスト全体（延べ 語数）の何パーセントを占めるかという指標である（Schmitt \& McCarthy, 1997: 328)。

3.リーダビリティ（readability）は、「文章を読みやすくする要因、すなわち 単語の難易、単語の長さ、センテンスの長さなどの要因を組み合わせ、公 式に代入して計算し、その数字を読書学年レベルとするものである」（高梨 ・卯城, 2000: 31）と定義される。

4. リーダビリティという指標を使用して大学入試に出題される読解問題の難 易度調査をしたものには他に、短期大学での調査をしたKimura \& Visgatis (1996)、四年制大学での調査をしたBrown \& Yamashita (1995a, 1995b)があ る。結果としていずれも、リーダビリティには幅があるものの、高校卒業 レベルとしては難易度が高すぎる問題を出題している短期大学、四年制大 学がかなりあることが指摘されている。

5. 閾值（threshold level）とは、「外国語の機能的な能力を達成するために必要 な最低限の言語熟達レベル」（リチャーズ他, 1988: 381）のことである。

6. たとえば、小池（2004：124）は、「第二言語学習者が習得目標とすべき語彙 とは、使われる頻度が高い、有用性のある語彙ということになろう」と述べ ている。また、西澤（2003：10）は、「日本人英語学習者という視点に立つ た語彙選定は次の 6 項目に配慮する必要がある」とし、(1)頻度、(2)汎用性、 (3)生活用語、(4)授業用語、(5)日本人にとっての有用性、6)力カナ英語、 を挙げている。このような意見を参考にし、本調査では、現在の日本人英 語学習者の置かれた状況を考慮し、学習した語彙が、ある特定の目的で使 用される可能性を想定して、「有用性」に焦点を当てることとした。

7. 高等学校用教科書には、上級、中級、基礎という学習者向けレベルがある とともに、大学入試には偏差值による大学のランク付けがある。これらの ことを考慮し、高等学校用教科書は上級レベルを使用した上で、大学入試 は偏差值ランク上位大学を受験した場合を想定し、その際に必要とされる 語彙力を、「語彙力の上限」と定義した。

8.「共通一次試験」が始まったのは1979年1月である。その後、1990年からは 「大学入試センター試験」となり現在に至っている（清水, 1997：16）。本研 
究で調査対象とする入試問題は、1980年代から2000年代までの範囲である ため、「共通一次・センター試験問題」と表記することにする。

9. 国立大学は2004年 4 月より「国立大学法人」となり、公立大学は2005年 4 月時点では随時「公立大学法人」に移行しているが、受験関係誌では国公立 大学という旧来の名称が使用されているため、本研究においてもこの呼称 に従う。

10、「16大学」とした理由は、本研究に先立って行った試算では、16大学を合計 した入試英語問題語彙の異語数は約 3,000 語となり、中高英語教科書語彙の 異語数とほぼ等しくなるため、両者を比較する上での量的目安として適当 であると考えたからである。

11. 1990年代の学習指導要領は、中学校で1991年に施行された 3 年後の1994年 に高等学校で施行されており、接続年度がつながっている。一方、1980年 代の学習指導要領では、中学校で1981年に施行された 3 年後の1984年が、 本来、高等学校での順当な施行年度と なるべきであるが、1982年施行とな っている。

12. 『2004年度大学入試 代ゼミデータリサーチVOL. 3』（代々木ゼミナール JEC日本入試センター，2003）、『2005年度国公立大・難易ランキング』 ベネッセコーポレーション，2004）、『2005年度私立大・難易ランキング』 （ibid.）を参考にした。

13. 結果的に、1988年入試は1982年 4 月〜1996年 3 月まで使用された教科書、 1998年入試と 2004 年入試は1994年 4 月〜2005年 3 月まで使用された教科書 となった。

14. 近年、日本において急速に受験者数の増加しているTOEICの大学専攻別受 験者数の内訳（TOEIC運営委員会, 2005: 7) によれば、1 位が語学・文学系 （英語専攻）、2 位が社会学系（商・経・法）である。このような英語運 用能力に対する関心の高さという観点と、実際に入手できた大学入試問題 という現実的理由から、文学部 (英文科) と経済学部の問題を調査対象と した。

15. 2005 年から首都大学東京と大学名を変更したが、調査対象とした入試問題 は2004年までのものなので旧来の大学名を用いる。

16. 出典の詳細は、長谷川・中條（2004: 153）より次のとおりである。

17. 旺文社（2004a，2004b）によれば、2004年度入試の英語問題全体に占める読 解問題の割合は、国公立大で $73.5 \%$ 、私立大で $52.5 \%$ あ゙あた。また、安竹 内（1997）でも指摘されているように、現在の入試英語を支えている特徵 のひとつは、読解問題の長文化である。これらのことを考慮に入れると、 本研究では英語問題全体で使用される語彙を対象にしているが、その過半 数は読解問題で使用された語彙で、特徵語の多くは長文読解問題に起因し ているのではないかと推定できる。

18. 羽鳥他（1979：110）によれば、未知語に遭遇する割合が20語に 1 語であれ ば、なんとか英語のテキスト理解が可能であるという。したがって、20語 よりも少なければ理解が困難であると考えられる。20語に 1 語というの は、95\%カバー率に該当する。 


\section{参考文献}

安竹内ひろし（1997）。「大学入試英語問題一覀い問題・良い問題」。『現代英語教育』, 第34巻，第8号，4-9.

別府有紀（2003）。「大学入試が高校英語教育に対して与える影響」。『関東甲信越英語教 育学会研究紀要』，第17号，77-88.

中條清美・長谷川修治・竹蓋幸生（1993）。「日米英語教科書の比較研究から」。『現代英 語教育』，第29巻，第12号，14-16.

中條清美・長谷川修治（2003）。「時事英語の授業で用いられる英文素材の語彙レベル調 査一BNC (British National Corpus) を基準にして一」. 『時事英語学研究』, No. XLII. 51-62.

中條清美・長谷川修治（2004）。「語彙のカバー率とリーダビリティから見た大学英語入 試問題の難易度」『日本大学生産工学部研究報告B』，第37巻，45-55.

中條清美・内山将夫・長谷川修治（2005）。「統計的指標を利用した時事英語資料の特徵語 選定に関する研究」『英語コーパス研究』，第12号, 19-35.

長谷川修治（2003）。「英検2級とセンター試験に対する英語教科書語彙の効果一過去 10年間の通時的調査」『『STEP BULLETIN』，Vol. 15，日本英語検定協会，152-158. 長谷川修治・中條清美（2004）。「学習指導要領の改訂に伴う学校英語教科書語彙の時代 的変化一1980年代から現在まで」。 『Language Education \& Technology』，第41号，外 国語教育メディア学会（LET），141-155.

羽鳥博愛他（1979）。『英語指導法ハンドブック 4 <評価編 >』. 東京 : 大修館書店. 林洋和（2002）。『英語の語彙指導一理論と実践の統合をめざして』. 広島 : 渓水社. 深沢清治（1999).「大学入試悪者論を越えて」。『現代英語教育』，第35巻，第12号， 59.

伊村元道（2003）。『日本の英語教育200年』。東京 : 大修館書店.

時事通信社. 『内外教育』。(12/18,1987；12/10,1993; 1/10,1995; 1/26,1996; 1/14,1997; 1/16,1998; 1/26,1999; 1/14,2000; 1/16,2001; 1/30,2001; 1/11,2002; 12/3,2002).

苅谷剛彦（2003）。『なぜ教育論争は不毛なのか一学力論争を超えて』。東京：中央公論 新 社.

片山七三雄・大谷道子・金谷憲（1997）。「変わりゆく入試英語と高校での対応」。『英語 展望』, No. 104, Summer, 19-24, 14.

川澄哲夫（編）(1978). 『資料日本英学史2 - 英語教育論争史』. 東京 : 大修館書店.

小林功（2000）。「2000年度の大学入試問題の傾向と今後の課題一改善が見られない大 学入試問題」。『英語教育』，第49巻，第3号，12-15.

小林功（2003）。「入試の英単語と学習法を巡って」。『英語通信』，第33号，8-9.

小池生夫（編集主幹）（2004）。『第二言語習得研究の現在一これからの外国語教育への 視 点』. 東京 : 大修館書店.

文部科学省（2003）。「『英語が使える日本人』の育成のための行動計画」.

新里眞男（1990）。「高校から大学入試を見ると」。『英語教育』，第39 巻，第9号，2223.

西澤正幸（2003）。「語彙数はどれだけ必要か？」。英語教育』，第52巻，第７号，810.

旺文社（2004a）。『2005年受験用全国大学入試問題正解 英語（国公立大編）』. 旺文社（2004b）。『2005年受験用全国大学入試問題正解 英語（私立大編）』. リチャーズ, J.・プラット, J.・ウェーバー, H.（山崎真稔 他訳）（1988）。『ロングマン応 用言語学用語辞典』。東京：南雲堂.

酒井邦秀（1996）。『どうして英語が使えない?』。東京 : 筑摩書房. 
佐藤学（2001）。『学力を問い直す一学びのカリキュラムへ一』，岩波ブックレット，

No. 548. 東京: 岩波書店.

清水裕子（1997）。「大学入試センター試験」の変遷一問題構成と配点をもとに」『『英語

教育』，9月増刊号，Vol. 46，No. 7, 16-18.

出版労連（1987）。『教科書レポート』, No. 31 .

出版労連（2002）。『教科書レポート』, No. 46.

高梨庸夫・卯城祐司（2000）。『英語リーディング辞典』。東京 : 研究社出版.

武田一 (2004)。「2004年度入試を斬る! 一高校入試／センタ一試験／大学入試」。『英語 教育』，10月増刊号，Vol. 53, No. 8, 73-87.

谷口賢一郎（1997）。「新学習指導要領でセンター試験はどう変わったか」。『現代英語教 育』，第34巻，第 3 号，8-12.

田崎清忠（2000)。「日本人にとっての「英語力」を見極めよ」。『英語教育』，第 49巻, 第2号, 8-19.

TOEIC運営委員会（2005）。『TOEICテスト DATA \& ANALYSIS 2004』。東京 : 財団法 人国際ビジネスコミュニケーション協会.

投野由紀夫（編著）（1997）。『英語語彙習得論一ボキャブラリー学習を科学する』。東 京 :

河源社.

宇都裕・柳瀬実佳（2000）。『大学入試における「和訳」の比重と内容一1998年度大学入試 英語問題の徹底的研究 国・公立大学編、私立大学編の分析から一』。東京: 学校 法人 文京学園 文京語学教育研究所.

若林俊輔（1988）。「入試英語」。『英語教育』，9 月増刊号，Vol. 37, No. 7, 65-67.

Watkins, G.・河上道生・小林功（1997）。『これでいいのか大学入試英語』（上下巻）. 東京 : 大修館書店.

Beppu, Y. (2001). An analysis of the university entrance examinations focusing on some sentence structures. 『東京学芸大学大学院英語研究会紀要(LEO)』，31， 35-60.

Brown, J. D., \& Yamashita, S. O. (1995a). English language entrance examinations at Japanese universities: What do we know about them? JALT Journal, 17(1), May, 7-30.

Brown, J. D., \& Yamashita, S. O. (1995b). English language entrance examinations at Japanese universities: 1993 and 1994. In J. D. Brown \& S. O. Yamashita (Eds.), Language testing in Japan (pp. 86-100). Tokyo: JALT.

Chujo, K. (2004). Measuring vocabulary levels of English textbooks and tests using a BNC lemmatized high frequency word list. In J. Nakamura, N. Inoue, \& T. Tabata (Eds.), English corpora under Japanese eyes (pp. 231-249). Amsterdam: Rodopi.

Chujo, K. \& Utiyama, M. (2005a). Understanding the role of text length, sample size and vocabulary size in determining text coverage. Reading in a Foreign Language, 17(1), 1-22. <http: / / nflrc.hawaii.edu/rfl/>.

Chujo, K. \& Utiyama, M. (2005b). Exploring sampling methodology for obtaining reliable text coverage. Language Education E Technology, No. 42, 1-19. 
Kimura, S., \& Visgatis, B. (1996). High school English textbooks and college entrance examinations: A comparison of reading passage difficulty. JALT Journal, 18(1), 81-95.

Laufer, B. (1997). The lexical plight in second language reading: Words you don't know, words you think you know, and words you can't guess. In J. Coady \& T. Huckin (Eds.), Second language acquisition (pp. 20-34). Cambridge: Cambridge University Press.

Matsuo, H. (2000). An analysis of Japanese high school English textbooks and university entrance examinations: A comparison of vocabulary. ARELE, 11, 141-150.

Mulvey, B. (1999). A myth of influence: Japanese university entrance exams and their effect on junior and senior high school reading pedagogy. JALT Journal, 21(1), 125-142.

Nation, I. S. P. (2001). Learning vocabulary in another language. Cambridge: Cambridge University Press.

Read, J. (2000). Assessing vocabulary. Cambridge: Cambridge University Press.

Schmitt, N., \& McCarthy, M. (Eds.) (1997). Vocabulary: description, acquisition and pedagogy. Cambridge: Cambridge University Press.

Scott, M. (1999). WordSmith Tools Manual [Computer Software]. Oxford: Oxford University Press. 